\title{
Politisk kommunikation set med system-briller
}

Peter Aagaard \& Mark Blach-Ørsten, 2018

Politisk kommunikation: Nye tider og nye aktører

Hans Reitzels Forlag, København

240 sider, 269,95 kroner

Anmeldt af Christian Erik J. Kock, Professor ved Institut for Medier, Erkendelse og Formidling, Københavns Universitet

Politisk kommunikation er et imponerende og ambitiøst forsøg på at overskue en række forskningsfelter, der er vokset eksponentielt de sidste årtier. Man kan ud fra forordet slutte sig til, at den især er tænkt som lærebog på universitetsniveau, men også undervisere på flere fakulteter vil kunne lære meget af den.

Denne anmeldelse skrives af en udenforstående i forhold til forfatternes fagområder: en humanist, der studerer politisk kommunikation fra en retorisk synsvinkel. Jeg vil præsentere bogen og dens grundideer nærmere og fremhæve, hvor jeg især mener, man kan blive klogere af den. Jeg vil nævne, hvordan jeg synes, bogen kunne have været endnu nyttigere både som lærebog og som akademisk monografi - måske med henblik på en senere udgave. Jeg vil pege på, at forfatterne alene har fokuseret på visse sider af emneområdet politisk kommunikation og forbigået andre. Min konklusion er, at bogen viser, hvor meget der må være at vinde $\mathrm{i}$ forskningen om politisk kommunikation hvis forskellige discipliner i hhv. samfundsvidenskab og humaniora kommunikerede mere indbyrdes og lærte af hinanden.

Bogen anlægger "et klart politologisk og mediesociologisk perspektiv" (s. 17) og tegner derudfra sit billede af "nye tider og nye aktører". En grundidé er, at vi befinder os er i en fjerde fase af den politiske kommunikations udvikling. Denne fase går ca. tilbage til 2006, hvor "den mobile datateknologi" brød igennem og indvarslede et "hybridt" mediesystem. Sammenlignet med den tredje fase, "konkurrencestaten" (1984-2006), bringer den fjerde tidsalder en intensiveret kappestrid om reklameindtægter og publikums opmærksomhed. Offentligheden fragmenteres, og sociale mediers fremvækst multiplicerer både muligheder og udfordringer. Her træder så en ny klasse af aktører ind på scenen: de policy-professionelle. De er eksperter med bredspektrede kompetencer; de er ikke valgt, men ansat, f.eks. i tænketanke, til at påvirke landets politik. De er partiske og arbejder mere skjult fra offentligheden end politiske aktører gjorde før, f.eks. de tidligere 
korporative aktører i råd og interesseorganisationer o.l. De er som type en hovedperson både $\mathrm{i}$ den fjerde tidsalder og i bogen som sådan. Dermed er det ikke længere så let at skelne mellem politiske aktører, medier og borgere.

En vigtig begrebsdannelse hele vejen igennem er institutionelle logikker, som betyder at forskellige type institution - politik, marked, netværk, profession, medie - præger aktørers praksis og identitetsopfattelse på særlige måder. Men i den fjerde tidsalder blandes disse institutionelle logikker i nye hybridformer - ikke mindst hos de ressourcestærke nye policy-professionelle.

Bogen igennem bliver en læser som denne anmelder, med humanistisk baggrund, meget klogere på de systemer, strukturer, institutioner m.v., der utvivlsomt er stærkt determinerende for, hvordan den politiske kommunikation former sig og fungerer. Men man bliver også overrasket over, hvad "et klart politologisk og mediesociologisk perspektiv" synes at indebære.

Tilspidset sagt: Titlen Politisk kommunikation er en oversælgende varedeklaration. Bogens fokus er nemlig ikke selve den faktiske kommunikation, men som undertitlen siger: nye tider, nye aktører. En bedre titel til bogen havde f.eks. været Det politiske kommunikationssystem. Forfatterne siger de vil "give den første samlede beskrivelse af, hvordan politisk kommunikation i den nye tidsalder former sig" (s. 15), men de berører næsten ikke, hvordan selve kommunikationen faktisk former sig. Vi hører ikke om forskning i de ytringer, udsendelser, artefakter, m.v., der $u d g ø r$ den politiske kommunikation - kun om de institutioner, systemer, logikker og aktører, som frembringer og determinerer kommunikationen.

At bogen intet siger om ytringer, tekster, genrer af tekster, m.v., eller om forskning heri, kan man se som udslag af en legitim disciplinær begrænsning - og trods den, er det alligevel imponerende, hvor meget forskning forfatterne har formået at overskue og formidle. Men jeg tror, at bogen havde været mere hensigtsmæssig både som lærebog og introduktion, hvis den f.eks. havde belyst de policy-professionelles virke gennem et par autentiske cases - med kommentar og analyse af konkrete kommunikative produkter til at tydeliggøre logikkernes aftryk på det aktørerne laver. Man kunne eksempelvis som en illustrativ case tænke sig CEPOS - en af de nye tænketanke, hvor de policy-professionelle typisk er baseret.

Generelt forekommer det mig, at bogen med sit dybtgående, men decideret partielle system-blik på et emneområde viser, hvor stort ekstra udbytte alle kunne have ved mere kontakt mellem grene af samfundsvidenskab og humaniora, der har fælles interesser. Politisk kommunikation er netop et centralt emne for begge.

Bogen gør det indlysende, at humanistiske fag og forskere - der jo også studerer strukturer, systemer og udviklinger, men ofte koblet med kvalitative studier af tekster og andre artefakter - har meget at lære ved at tale med samfundsvidenskabelige forskere, der som i denne bog ofte søger fugleperspektivet på lovmæssigheder og "logikker", idealtyper, trends og megatrends. Men udbyttet kunne gå begge veje. Tag tilfældet CEPOS, som oplagt har haft succes - hvilket en samfundsvidenskabelig tilgang kunne begynde med at dokumentere empirisk. CEPOS-økonomen Mads Lundby Hansen var f.eks. i 2012 årets 
mest citerede danske økonom og var på Politikens liste over "de mest dagsordensættende debattører". Bogen siger selv om den "policy-professionelle stat" at kommunikation fra visse organisationer "er stærkt tilrettelagt af professionelle kommunikatører" (s. 196). Men hvordan kommunikerede CEPOS egentlig, og hvad var det "stærke" og "professionelle" ved det? Det kan man ikke sige meget om uden kvalitativt at studere selve kommunikationen. Noget sådant har jeg selv leveret et første forsøg på i bogen Umyndiggørelse (red. Cecilie Eriksen og Joel Haviv, i serien Moderne arbejdsliv, 2015). Samtidig er det klart at en tekstbaseret analyse som min kunne være nået flere spadestik dybere ved en udvidet forståelse af det mediesystem og de institutionelle logikker som CEPOS' kommunikation indgår i.

Bogen nævner selv flere eksempler på forskning, hvor det forekommer mig oplagt, at en medie- og systemorienteret tilgang og en analyse af konkret kommunikations indhold og egenskaber kunne mødes. Det noteres f.eks. (s. 167), at kendte politikere ved 2015-folketingsvalget stadig foretrak traditionelle medier frem for Twitter, men også at en af valgets topscorere, Thulesen Dahl, var langt mindre til stede i de traditionelle medier end bl.a. Løkke og Thorning. Oplagt kommentar: For at forstå denne skævhed, burde man ikke blot betragte kvantiteten af givne politikeres optræden på forskellige medier, men også indholdet af denne optræden og dens konkrete egenskaber, samt hvordan deres kommunikation i det hele taget var.

Det nævnes videre (også s. 167), at man i valgkampforskning ser et mere etnografisk fokus: Forskere følger partier og kandidater tæt. Også retoriske forskere har i disse år flyttet sig fra rene tekststudier i retning af "field"-forskning, hvor man ser kommunikation $i$ kontekst. Kunne samfunds- og humanistiske forskere ikke mødes om at se på kandidaternes faktiske kommunikation - og måske gå videre til kommunikationen i samtaler og på sociale medier mellem almindelige borgere (som ikke optræder i de traditionelle medier)? Her tillader jeg mig at spørge, om ikke den vildtvoksende, uredigerede mangetil-mange-kommunikation om politiske temaer havde fortjent mindst lige så stor en plads som de policy-professionelle i fortællingen om den "fjerde tidsalder"?

Aagaard og Blach-Ørsten spørger om bagsiden af professionelle kommunikatørers stærke kommunikation er et "tilskuerdemokrati", og de nævner ofte ønskeligheden af "en oplyst, demokratisk debat" (bl.a. s. 208). De siger endvidere, at "datalogikken" med dens "kvantificerbare variable, formelle metoder og alt, hvad der er håndgribeligt" præger den måde hvorpå vi "identificerer, kategoriserer, analyserer og tilrettelægger politisk kommunikation" (s. 77) - men, spørger de, vil en sådan videnskabeliggørelse "fortrænge samtaledemokratiske idealer"? Ligeledes: Vil et kommende Google- og Facebook-duopol vil udvikle sig "på bekostning af samtale- og deltagelsesdemokrati” (s. 203). Jeg hilser velkommen, at de mediesociologisk orienterede forfattere dermed signalerer normativitet - altså at noget er godt og andet mindre godt, og at forskere også kan og bør sige noget om dét. Men de diskuterer ikke, hvad de mener med de her citerede begreber og henviser ikke til teori og forskning om dem. Det er endnu et område, hvor både politisk teori og humanistisk, diskursbaseret forskning kunne bidrage til et samarbejde - og begge dele eksisterer jo i stort omfang. 
Bogens tilgang lægger som sagt teorier om strukturer, institutioner og logikker til grund, men taler ikke om selve kommunikationen. Sådan en tilgang kan friste til en tænkemåde hvor mennesker - både som individer og som grupper - kun tillægges minimal selvstændig handleevne ("agency"). Synsmåden bliver ekstra fristende hvis aktørerne i den politiske kommunikation alene anskues som handlende ud fra visse logikker. Det gælder også med hensyn til modtagerne af kommunikationen - og dermed borgerne, vælgerne.

Forfatterne nævner selv, at de f.eks. har givet "meget begrænset omtale" til receptionsforskning (s. 17). I det hele taget siger de nærmest intet om modtagersiden, f.eks. om hvilke egenskaber i kommunikationen, der synes at virke eller blive modtaget på hvilke måder hos modtagere. Det er i eminent grad problemstillinger, der bedst kunne belyses ved kombinationer af humanistisk og samfundsvidenskabelig begrebsdannelse og metodik. Og de spørgsmål må interessere alle, der hylder "samtaledemokratiske idealer". Er borgernes meningsdannelse f.eks. drevet af, at de simpelthen støtter den politik, som de rationelt tror kan maksimere deres egennytte (som "rational choice"-teorier siger)? Er meningsdannelsen dermed fikseret ud fra uforanderlige interesser ("præferencer")? Eller kan borgeres meninger reelt flyttes og ændres af samtale og argumenter - som deliberative demokratiteoretikere insisterer på? Er samtale dermed et afgørende element i et demokrati? Er argumentation? Hvor godt står det for resten til med den politiske samtale og den politiske argumentation - i de traditionelle medier, i de sociale medier og mand og kvinde imellem?

Denne byge af spørgsmål skal antyde, at politisk kommunikation er for vigtig til at overlade til ét forskningsparadigme. Bogen her gør læseren meget klogere på de samfunds- og mediemæssige vilkår for politisk kommunikation i vor tid. Men den bevidstgør også, at vi ikke forstår nok om politisk kommunikation, hvis den udforskes af separate forskningskulturer, der - måske i en iver for specialisering - arbejder med ryggen til hinanden.

\section{Litteratur}

Kock, C.E.J. (2015). Det skal kunne betale sig at tage et arbejde. I: Eriksen C. \& Harviv J. (red). Umyndiggørelse. Aarhus: Klim, Moderne Arbejdsliv, årg. 4, s. 151-169. 